\title{
Analysis of the didactic use of tablets in the European Higher Education Area
}

\author{
M. a Luisa Sevillano García' \\ and Esteban Vázquez Cano ${ }^{2}$ \\ 1. National University of Distance Education (UNED), Spain | mlsevillano@edu.uned.es \\ 2. National University of Distance Education (UNED), Spain | evazquez@edu.uned.es
}

Submitted in: April 2013 Accepted in: February 2014 Published in: July 2014

\section{Recommended citation}

Sevillano, M.L. \&Vázquez, E. (2014). Analysis of the didactic use of tablets in the European Higher Education Area. RUSC. Universities and Knowledge Society Journal, 11(3). pp. 63-77. doi http://dx.doi.org/10.7238/rusc.v11i3.1808

\begin{abstract}
This article presents a study in which we analyse the didactic use of tablets in the European Higher Education Area (EHEA). The competential and didactic use of mobile devices is a challenge for lecturers, students and universities alike. In the current university system, mobile devices play a key role that requires rigorous analysis to open up new channels of participation and didactic design in accordance with the EHEA. The research is contextualised in a sample of 419 students from three Spanish public universities: Complutense University of Madrid (UCM), University of Oviedo and National University of Distance Education (UNED), Spain. Through a quantitative and qualitative methodological approach, we proceeded to analyse the life stories of students who are familiar with tablets and use them in both their personal lives and for their university studies. The results show that this mobile device can be a useful resource in information processing, content access and creation, and generic competency development in line with the Dublin Descriptors and the main recommendations of the Tuning, Reflex and EUConverge European projects.
\end{abstract}

\section{Keywords}

tablets; mobile and ubiquitous learning; generic competencies; EHEA

\section{Análisis de la funcionalidad didáctica de las tabletas digitales en el espacio europeo de educación superior}

\section{Resumen}

Este artículo presenta una investigación en la que se analiza la funcionalidad didáctica de las tabletas digitales en el espacio europeo de educación superior. El uso didáctico y competencial de los dispositivos móviles es un reto al que se enfrentan profesores, alumnos y las propias instituciones universitarias. En el actual sistema universitario, los dispositivos móviles desempeñan un papel esencial que precisa de análisis rigurosos que abran nuevas vías de participación y arquitectura didáctica acordes con el espacio europeo de educación superior. La investigación se ha contextualizado en una muestra de 419 estudiantes de tres universidades públicas españolas: Universidad Complutense de Madrid, Universidad de Oviedo y Universidad Nacional de Educación a Distancia (UNED). A través de una metodología cuantitativa y cualitativa, 
se ha procedido a analizar historias de vida de estudiantes que conocen y usan las tabletas digitales de forma personal y en sus estudios universitarios. Los resultados muestran cómo este dispositivo móvil puede llegar a ser un recurso muy útil en el tratamiento de la información, en el acceso y creación de contenidos y en el desarrollo de competencias genéricas conforme con los descriptores de Dublín y con las principales recomendaciones de los proyectos europeos Tunning, Reflex y UEConverge.

\section{Palabras clave}

tabletas digitales; aprendizaje ubicuo y móvil; competencias genéricas; EEES 


\section{Introduction}

In this article, we present an analysis of the didactic potential of using tablets in the European Higher Education Area (EHEA), contextualised in three Spanish universities: Complutense University of Madrid (UCM), University of Oviedo and National University of Distance Education (UNED), Spain. This device has burst onto the scene in Spain, a country where the number of tablets per user is twice that of the European average; 14\% in Spain compared to 7\% in Europe according to the Mobile Life report (2012). Applying the use of mobile devices to the development of personal, academic and professional skills falls within the competency framework of the EHEA. The key concept adopted within this university action framework is the use of methodologies and instruments that foster the transferability of skills to personal, social, academic and professional contexts, thus laying the foundations for lifelong learning (Villa \& Poblete, 2007; Cedefop, 2010; Murphy, 2011; Allen \& Van der Velden, 2012). To this, we should add that all experts have highlighted the fact that one of the paths that needs to be explored in order to overcome the current economic crisis is that of intelligently adopting digital technologies that enable efficient and productive economic models to be developed, in which technological innovation serves as a driver of growth and increased productivity (La sociedad en red, 2011).

The aim of this study is to analyse whether this digital device, which has a high level of penetration in today's social context, is of benefit to university students in their academic, professional and social advancement as a result of it contributing to the development of instrumental knowledge and attitudes that are of value to the knowledge society.

\section{Didactic implications of tablets in the EHEA}

The European Union has pointed out that, in the knowledge society, every citizen will need a broad range of competencies to adapt, in a flexible manner, to a world that is rapidly changing and has multiple interconnections (European Commission, 2010). The generic competencies in the EHEA refer to those that are key, cross-disciplinary and transferrable to a wide variety of personal, social, academic and professional contexts throughout life. Therefore, the generic competencies are (Villa \& Poblete, 2007):

- Those that constitute a fundamental part of the professional and formative profiles of all or most degrees.

- Those that include a set of cognitive and metacognitive skills, instrumental knowledge and attitudes of great value to the knowledge society.

The main reasons for including competencies of this type derive, on the one hand, from institutions and firms that employ university graduates, who demand competency-based training so that they can count on human resources that not only possess technical competencies, but also methodological, human and social competencies. In other words, university graduates should have all those competencies relating to the ability to act effectively in specific work-related situations and in life in general (García-Aracil \& Van der Velden, 2008).

When a student performs a practice within a ubiquitous digital ecosystem, he or she is subject to a series of stimuli that flow between nodes located on different media and that filter information through a variety of channels, each 
Table 1. Relationships between generic competencies and tablet uses

\begin{tabular}{|c|c|}
\hline Tablet uses & $\begin{array}{l}\text { Generic competencies } \\
\text { (Dublin Descriptors, 2005) }\end{array}$ \\
\hline $\begin{array}{l}\text { Managing social networks (Twitter, Facebook...) and all types of } \\
\text { forum. } \\
\text { Making video calls, posting messages to microblogging sites and } \\
\text { making Voice over Internet Protocol calls (VolP) with no additional } \\
\text { cost. }\end{array}$ & $\begin{array}{l}\text { Self-directed learning competencies } \\
\text { Autonomous learning. } \\
\text { Initiative and motivation. } \\
\text { Planning and organisation. } \\
\text { Proper time management. } \\
\text { Attention to quality (monitoring, assessment, improvement). }\end{array}$ \\
\hline $\begin{array}{l}\text { Reading digital documents and books using office automation } \\
\text { applications, e-readers, RSS feed readers. } \\
\text { Using GPS systems, map viewers (Google Maps, Google Earth...), } \\
\text { route planners. } \\
\text { Environment sensors: weather station, gyroscope and accelerometer, } \\
\text { compass and magnetic field detector, light and noise level } \\
\text { measurement. }\end{array}$ & $\begin{array}{l}\text { Higher cognitive competencies } \\
\text { Capable of synthesis. } \\
\text { Capable of analysis. } \\
\text { Creative and innovative thinking. } \\
\text { Capable of problem-solving/taking action in new environments. } \\
\text { Applying knowledge to practice. } \\
\text { Decision-making. } \\
\text { Critical judgment (of one's own and others' work). }\end{array}$ \\
\hline $\begin{array}{l}\text { Making video calls. Playing multimedia and FM radio: images, videos, } \\
\text { animations, music and other audio files. } \\
\text { Recording audio, and image, video, and sound editing (with various } \\
\text { applications). } \\
\text { Word and text translator into multiple languages (with voice playback } \\
\text { and voice input of words). } \\
\text { OCR scanner of PDF documents and images. }\end{array}$ & $\begin{array}{l}\text { Communication competencies } \\
\text { Written communication and presentation. } \\
\text { Oral communication and presentation. } \\
\text { Capable of writing reports or formal documents. } \\
\text { Capable of communicating in foreign languages. }\end{array}$ \\
\hline $\begin{array}{l}\text { Information searching (press, thematic websites, videos... with voice } \\
\text { navigation capability) and downloading files. } \\
\text { Cloud storage/retrieval of data (synchronising content in DropBox, } \\
\text { Google Drive, SkyDrive...). } \\
\text { Viewing tablet content on a television or digital whiteboard. } \\
\text { Camera (QR code scanner and reader) and video recorder (with } \\
\text { applications for viewing augmented reality). } \\
\text { Note-taking: notes and bookmarking, photos and all sorts of } \\
\text { information from the Internet. } \\
\text { Using simple office automation tools to create and change text } \\
\text { documents and spreadsheets. }\end{array}$ & $\begin{array}{l}\text { Instrumental competencies in the knowledge society } \\
\text { Handling information and communication technologies (ICTs). } \\
\text { Ability to search for information. } \\
\text { Ability to organise information. } \\
\text { Ability to handle databases. }\end{array}$ \\
\hline $\begin{array}{l}\text { Management (synchronised in the cloud) of user e-mail accounts, } \\
\text { contacts and online calendars. } \\
\text { Managing social networks (Twitter, Facebook...) and all types of } \\
\text { forum. } \\
\text { Making video calls. } \\
\text { Using instruments to create and share documents: blogs, posters, } \\
\text { concept maps, comics, stories. }\end{array}$ & $\begin{array}{l}\text { Interpersonal competencies } \\
\text { Capable of effective negotiation/conflict resolution. } \\
\text { Capable of coordinating. } \\
\text { Capable of working in a team/collaborative work. }\end{array}$ \\
\hline
\end{tabular}

with its own narrative and symbolic code (Pachler, Bachmair \& Cook, 2010; Siemens \& Baker, 2012). In particular, these stimuli require decision-making, which will be connected with prior available information, but whose process has a cognitive charge capable of generating new learning (Franklin, 2011; Barbosa, Barbosa \& Wagner, 2012). The interrelation between cultural practices, structures and actions gives rise to a new form of ecology that manifests itself in a process of emergent education and cultural transformation. The so-called user-generated contexts prevail 
in this ecology (D'Orio, 2011; Walters \& Baum, 2011). The users are those who actively participate in the production of their own forms of content creation, and they present their conception of knowledge within an area of personal learning (Van't Hooft \& Swan, 2007; Cope \& Kalantzis, 2009). From the students' perspective, the key factors for educational innovation will be the competency need, and to implement the mobility needs for a global higher education that is not bound by borders, a process that is currently being promoted by massive open online courses (MOOCs). There is a direct relationship between the idea of ubiquitous learning and the ability of mobile devices to provide highly interconnected educational environments. The latest studies show that learning anywhere is equivalent to some form of simple mobile learning (Murray \& Olcese, 2011; Vázquez, 2012; Sevillano \& Quicios, 2012).

The use of mobile devices like tablets in learning processes gives rise to situations of ubiquity in which devices and formative activities converge within contexts of applied social practice (Caudill, 2007; Billinghurst \& Dunser, 2012). Table 1 shows the relationship between the most common applications and uses of tablets, and the generic competencies of the EHEA (Dublin Descriptors, 2005).

\section{Study design and objectives}

The aim of this study is to analyse the use that university students make of tablets and its impact on improved academic performance and on generic competency acquisition in accordance with the EHEA in face-to-face and distance modes. Our intention is to create a regulated standard of competencies and their didactic uses, which can be employed by various agents in different usage scenarios. Our starting point was the following research hypothesis: mobile digital devices like tablets, applied in the EHEA setting, are an innovative alternative that could potentially lead to an improvement in the various indicators of generic competency development. In order to develop this research hypothesis, we set the following objectives:

1. To determine the benefits of the didactic use of tablets in a university context.

2. To document the map of competencies acquired with digital tablets in the EHEA.

3. To identify tablet utilities, programs, uses and activities for their application to the EHEA.

\section{Methodology}

This work took a multiple case study approach and it falls within the generic field of qualitative methods of descriptive research based on multi-situated ethnography using coded life-story data collected from in-depth interviews. Research on technologies in learning environments is more and more complex, and, as De Pablo, Colas and Villaciervos (2010) have pointed out, studies are being reoriented towards a qualitative approach because it enables a more in-depth knowledge of the impact that they have. Thus, by means of biographical-narrative research, we performed an in-depth analysis of a micro-contextual unit that mainly seeks to describe and understand the use of tablets in the development of higher education studies in a group of university students in three distinct contexts, therefore allowing us to get an overview of the situation. 


\section{Sample}

The data collection process was performed throughout the 2011/2012 academic year in three Spanish universities: Complutense University of Madrid (UCM), University of Oviedo and National University of Distance Education (UNED). A total of 419 valid interviews and questionnaires was obtained. After eliminating spurious and duplicated data, the questionnaires were grouped into the following categories for analysis: gender, age and knowledge area (Table 2).

Table 2. Participating sample, by category and university

\begin{tabular}{|l|c|c|c|c|}
\hline \multirow{4}{*}{ Gender } & Categories & UCM & University of Oviedo & UNED \\
\cline { 2 - 5 } & Female & 79 & 67 & 93 \\
\hline \multirow{3}{*}{ Age } & Male & 49 & 51 & 80 \\
\hline \multirow{4}{*}{ Area } & $18-22$ & 57 & 60 & 101 \\
\cline { 2 - 5 } & $23-26 \geq$ & 44 & 54 & 103 \\
\cline { 2 - 5 } & Arts-Hum. & 28 & 12 & 32 \\
\cline { 2 - 5 } & Sciences & 30 & 15 & 41 \\
\cline { 2 - 5 } & Social Sciences & 41 & 24 & 0 \\
\cline { 2 - 5 } & Health Sciences & 42 & 26 & 37 \\
\hline \multirow{2}{*}{ Totals } & Architect.-Engineering & 44 & 20 & $(\mathrm{~N}=173-41.28 \%)$ \\
\hline
\end{tabular}

\section{Instruments and data analysis techniques}

The data was collected by means of recorded interviews, with a digital recorder and in audio file format. In addition to the interviews, Likert scale questionnaires were completed, which provided us with data on frequency of use, programs and activities. The guidance protocol for the standard statements used in the interviews was divided into three thematic areas: "Activities" done, which complement learning and fall within the field of strategies, "Benefits" of knowledge and procedures obtained, and "Programs and apps". Table 3 below shows the associated statements, by thematic area.

On completion of the interview process, we transcribed the interviews and used the Dragon program to convert audio to text. All the original files were converted to plain text files using WinEdt 5.6, and then the document data were cleaned and homogenised: deletion of internal format codes; deletion of characters and homogenisation of spelling; numbering of each competency, difficulty and benefit: processing of blocks, groups, sub-groups, options and itineraries. For the qualitative analysis, we used the technique of structuring text documents by means of text mining (QDA Miner 3.24), which mainly consists of determining a set of representative characteristics of those text documents (Witten \& Frank, 2005; Feldman \& Sanger, 2006; Miner et al., 2012; Castro \& Lizasoain, 2012). The methodology was based on identifying and extracting concepts, which can be considered as dimensions contained within the documents that together form a taxonomic system enabling the classification of a concept map of terms and expressions describing the designed objects. 
Table 3. Protocol, by thematic area of the interview

\begin{tabular}{|c|c|}
\hline Thematic area & Interview script statements \\
\hline Activities & $\begin{array}{l}\text { 1. Give a general explanation of what you use the tablet for in your university studies. } \\
\text { 2. State the main activities you do with the tablet. } \\
\text { 3. Describe whether you use the tablet to search for information and/or as a database. } \\
\text { 4. List your uses of the tablet for sharing online resources, using social networks and microblogging. } \\
\text { 5. Explain your use of the tablet for viewing, capturing and processing text, images, video and audio. }\end{array}$ \\
\hline Benefits & $\begin{array}{l}\text { 6. Indicate the main benefits of tablets in your university studies, as compared to other computer or digital devices. } \\
\text { 7. Specify the main functionalities that the tablet provides you with in your university studies. }\end{array}$ \\
\hline Programs and apps & $\begin{array}{l}\text { 8. Describe the main programs you use on your tablet. } \\
\text { 9. List the apps that you use the most to do your subjects. } \\
\text { 10. Specify the programs and apps that you consider to be the most productive and beneficial for use in the EHEA. }\end{array}$ \\
\hline
\end{tabular}

\section{Results and discussion}

The application of the aforementioned methodology allowed us to select a dictionary of concepts grouped by macro-category, referenced to the research concepts. This dictionary of concepts of components and subcomponents of the competency map of tablets contains a total of four macro-categories: didactic activities, programs and apps, benefits and generic competencies developed, for which 24 sub-components were coded as shown in Table 4 below.

Table 4. Map of components developed with tablets

\begin{tabular}{|c|c|c|}
\hline Macro-categories & \multicolumn{2}{|c|}{ Sub-components } \\
\hline Didactic activities & $\begin{array}{l}\text { 1. Online resource consultation. } \\
\text { 2. Text processor. } \\
\text { 3. Lecture notes. }\end{array}$ & $\begin{array}{l}\text { 4. Watching videos. } \\
\text { 5. Downloading educational resources. } \\
\text { 6. E-mail. }\end{array}$ \\
\hline Programs and apps & $\begin{array}{l}\text { 1. Microblogging. } \\
\text { 2. Image use. } \\
\text { 3. Games. }\end{array}$ & $\begin{array}{l}\text { 4. YouTube. } \\
\text { 5. Instant messaging. } \\
\text { 6. Social networks. }\end{array}$ \\
\hline Benefits & $\begin{array}{l}\text { 1. Communication. } \\
\text { 2. Time-saving. } \\
\text { 3. Mobility. }\end{array}$ & $\begin{array}{l}\text { 4. Leisure. } \\
\text { 5. Technical and social applications. } \\
\text { 6. Ubiquity. }\end{array}$ \\
\hline Generic competencies & $\begin{array}{l}\text { 1. Communication. } \\
\text { 2. Information processing. } \\
\text { 3. Digital. }\end{array}$ & $\begin{array}{l}\text { 4. Techniques and technicalities. } \\
\text { 5. Analysis and synthesis. } \\
\text { 6. Foreign language. }\end{array}$ \\
\hline
\end{tabular}

In order to categorise the concepts associated with the sub-components, WordStat software was used. It associated the concepts with the sub-components, with a total of 303 concepts corresponding to 24 sub-components and 4 macro-categories. After determining the sub-components and associated concepts, we obtained the proximity measure of concepts by Jaccard's coefficient (Tan et al., 2006: 74). The results showed that the corresponding concepts have quite a low level of similarity between them, which varies between 0.001 and 0.233 . These data indicate that the dictionary obtained is relevant for structuring the set of life stories associated with the use of 
tablets. We employed the technique of multidimensional scaling, for which we used the proximity measure of Jaccard's coefficient, to represent, in two dimensions, the set of sub-components and concepts associated with the macro-categories connected with the use of tablets in the EHEA. The result of this representation is shown in Figure 1.

Figure 1 shows the main distribution of components and sub-components that was obtained from the analysis of the life histories. We can see a distribution that allows us to identify the weight of the concepts associated with the four categories. The frequency of concepts is represented by the size of the circles. The application of the cluster analysis technique, using degree as an agglomeration variable and Jaccard's coefficient as a distance measure, enabled us to obtain the dendrogram shown in Figure 2.

Figure 1. Concept map of sub-components and concepts

Didactic activities

The dendrogram shows that the "Didactic activities" and "Benefits" categories are the two most notable ones, especially in the "Mobility", "Time-saving" and "Online resource consultation" sub-components. In descending order of importance, "Programs and apps" is the third category, in which the students value the use of "Social networks" and "Microblogging". It also shows that relationships of complementarity are established between categories; of note are the relationships established between "Competencies acquired", "Benefits" and "Didactic activities". Presented below are the quantitative results of the four most representative concepts, by macro-category.

Table 5. Frequency of didactic activities with tablets

\begin{tabular}{|l|c|c|c|c|c|c|}
\multicolumn{1}{|c|}{ Didactic activities } & No & $\%$ & Cases & \% of Cases & No of Words & $\%$ of Words \\
\hline Downloading educational resources & 20 & $30.3 \%$ & 20 & $40.8 \%$ & 1286 & $34.5 \%$ \\
\hline E-mail & 15 & $22.7 \%$ & 13 & $26.5 \%$ & 930 & $25.0 \%$ \\
\hline Online resource consultation & 22 & $33.3 \%$ & 21 & $42.9 \%$ & 1111 & $29.8 \%$ \\
\hline Lecture notes & 9 & $13.6 \%$ & 9 & $18.4 \%$ & 577 & $15.5 \%$ \\
\hline
\end{tabular}


Figure 2. Dendrogram of concept clustering, by macro-category sub-component

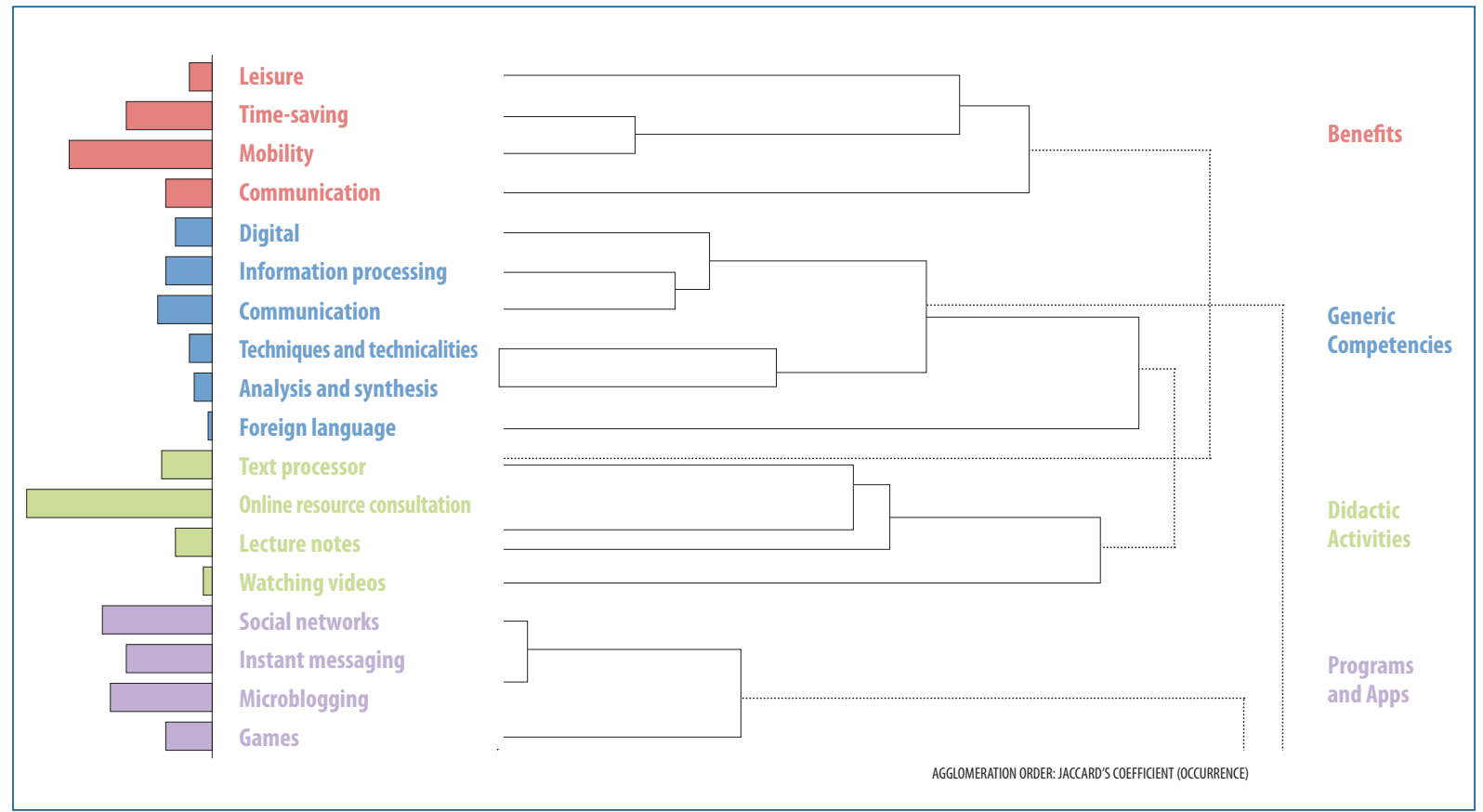

Table 5 shows the frequency of cases by the percentage of words associated with each sub-component. Of note are "Downloading educational resources" (n $1286=34.5 \%$ ) and "Online resource consultation" ( $n 1111=29.8 \%)$. The impact that tablets have on improving didactic processes associated with the day-to-day activities of lecturers and students is therefore significant.

Table 6. Benefits of tablets

\begin{tabular}{|l|c|c|c|c|c|}
\hline \multicolumn{1}{|c|}{ Benefits } & No & $\%$ & Cases & \% of Cases & No of Words \\
\hline Communication & 14 & $21.5 \%$ & 13 & $26.5 \%$ & 432 \\
\hline Time-saving & 19 & $29.2 \%$ & 16 & $32.7 \%$ & 450 \\
\hline Mobility & 10 & $15.4 \%$ & 10 & $23.8 \%$ & 146 \\
\hline Ubiquity & 11 & $16.9 \%$ & 11 & $22.4 \%$ & $19.1 \%$ \\
\hline
\end{tabular}

Table 6 shows the main sub-components associated with the "Benefits" category. In this category, two benefits stand out because of the number of times they were referred to in the biographies analysed: "Time-saving" ( $n 450$ $=24.8 \%$ ) and "Communication" ( $432=23.8 \%$ ). The benefits of using tablets translate into a strengthening of communication activities inside and outside the classroom for participation in academic chats and forums. This sub-component is crucial for the effective development of the competency map of the EHEA, as it promotes the students' ability to interpret a context and adopt strategies and skills for putting theoretical content into practice. Therefore, it incorporates a conceptual and attitudinal component into an action, which represents the philosophy of generic learning. 
Table 7. Use of programs and apps on tablets

\begin{tabular}{|l|c|c|c|c|c|c|}
\multicolumn{1}{|c|}{ Programs and apps } & No & $\%$ & Cases & \% of Cases & No of Words & $\%$ of Words \\
\hline Instant messaging & 10 & $15.9 \%$ & 9 & $18.4 \%$ & 257 & $18.1 \%$ \\
\hline Microblogging & 14 & $22.2 \%$ & 14 & $28.6 \%$ & 275 & $19.4 \%$ \\
\hline Social networks & 30 & $47.6 \%$ & 25 & $51.0 \%$ & 663 & $46.8 \%$ \\
\hline Games & 9 & $14.3 \%$ & 9 & $18.4 \%$ & 124 & $8.8 \%$ \\
\hline
\end{tabular}

Table 7 shows the programs and apps that are used the most on tablets. In this category, of particular note are the sub-components "Social networks" ( $663=46.8 \%$ ) and "Microblogging" ( $275=19.4 \%$ ). The fact that university students use these devices for social interaction is especially interesting. The e-learning and blended learning systems of all universities operate on the basis of platforms that integrate forum and chat functionalities, which are relevant aspects in social networks too.

We shall now go on to analyse the results relating to improvements in generic competencies by correlating three factors: gender, age and type of studies. Figure 3 shows the generic competencies acquired with the use of tablets, by sample participant gender. The analysis yields very even results. The students consider that the four competencies that improve the most with the use of tablets are "Communication" (26.5\%), "Information processing" (18.4\%), "Analysis and synthesis" (12.1\%) and "Digital" (8.3\%). The difference between genders indicates a higher percentage of women in the first two (5.1\% and 3.2\%, respectively) and of men in the last two (3.0\% and $4.3 \%$, respectively).

Figure 3. Generic competencies acquired with tablets, by gender

Analysis and synthesis


The development of these generic competencies by means of these technological resources is consistent with the recommendations made in the Tuning, Reflex and EUConverge European projects, among others, and by recent international researchers (Goral, 2011; Harrold, 2012). These four competencies help to provide a response to the levels required by the Dublin Descriptors (2005): autonomous and self-directed management of work; management of communication and information processes; teamwork, assuming different roles or functions. In addition to these macro-categories, we proceeded to analyse two dimensions that we considered relevant to better understand the repercussions of the use of tablets in the EHEA. To that end, and as shown in Figures 4 and 5, we analysed the variable "Age" (Figure 4) and the variable "Studies" (Figure 5) and their impact on the competencies acquired.

Figure 4 shows that age has an impact on the perception of competencies with the use of tablets in the EHEA. Thus, we can see that the older students are (age range 23-26 years), the more they value benefits such as commu-

Figure 4. Impact of the age variable on the use of tablets

Analysis and syntesis

Figure 5. Impact of the studies variable on the use of tablets

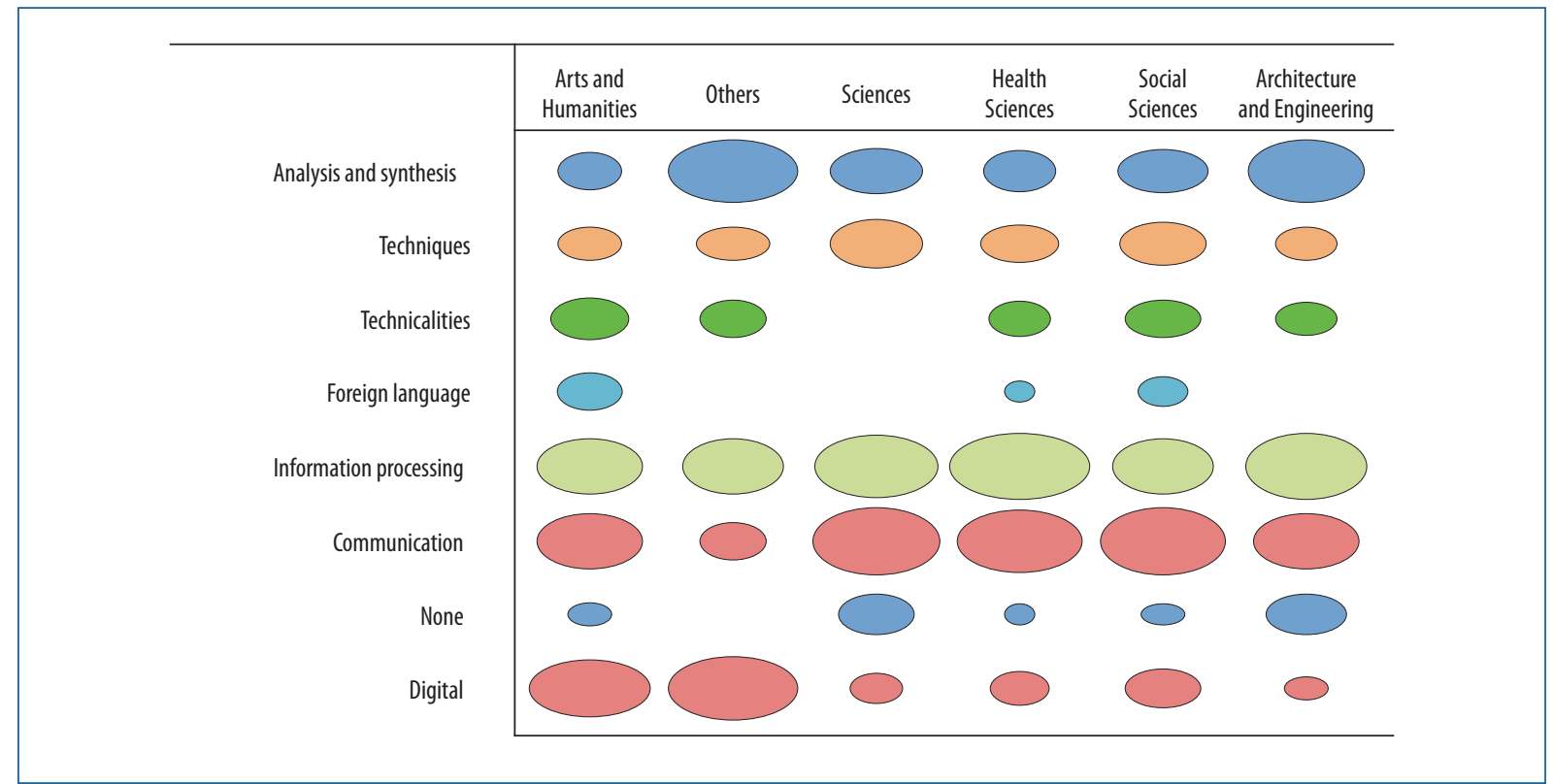


nication functionalities and time-saving. In contrast, the younger students are (age range 18-22 years), the more they value benefits such as ubiquity and leisure.

Figure 5 shows the percentages for generic competencies grouped by the studies on which the questionnaire analysis in the three universities was performed. Of note in the technical area of Engineering, Architecture and Sciences studies is that the students value the use of tablets as being especially useful for developing the competencies "Analysis and synthesis" (E: 25.93\% S: 15\%); "Technicalities" (E: 25.93\% S: 25\%) and "Information processing" (E: 18.52\% S: 30\%). Students of Humanities and Social Sciences highlight that tablets are useful for the competencies "Information processing" (H: 21.43\% SS: 27.62\%); "Technicalities" (H: 17.86\% SS: 18.83\%). Students of Health Sciences highlight that tablets are useful above all for two competencies, "Information processing" and "Technicalities" (HS: 26.32\%-31.58\%).

\section{Conclusions}

Twenty-first century universities are shaped not only by their institutional stance and governing regulations, but also by the social, professional and technological reality that permeates and moulds them. Ubiquitous learning undoubtedly constitutes a new educational paradigm that emerges from new media and technological resources that have principles of mobility, collaboration and active participation embedded within them. This learning offers alternatives for interaction and access to very diverse content. Tablets, which have burst onto the social and academic scene in the last two years, represent a powerful resource - because of their small size and high-performance technologies - for coping with the development of various sub-components of the generic competencies proposed in the EHEA. Moreover, this type of mobile device enables students to complete their training through MOOCs and work collaboratively and interactively with their fellow students and lecturers, in both face-to-face and distance education.

The results of this macro-study conducted on three Spanish universities have shaped one of the first competency maps of the use of tablets in the EHEA. We can conclude that this mobile device, which has a high level of penetration among the age group studied (18-26 years) enables improvements to be made in several generic competency indicators of the university student population. In particular, these improvements relate to "selfdirected learning competencies", "higher cognitive competencies", "communication competencies", "instrumental competencies in the knowledge society" and "interpersonal competencies" (Dublin Descriptors, 2005). Likewise, irrespective of age range, gender or university studies, those students who use these mobile devices highlight their usefulness and effectiveness in dimensions such as communication, information processing, time-saving, mobility and ubiquity.

\section{Support}

This work is part of the Project of the Directorate General for Research and Management of the National RD\&l Plan (Ubiquitous learning with mobile devices: creation and development of a competency map in higher education) EDU2010-17420-Sub-programme EDUC. 


\section{References}

Allen, J., \& Van der Velden, R. (2012). Skills for the 21st Century: Implications for Education. ROA-RM-2012/11. Maastricht: ROA, Maastricht University.

Barbosa, J., Barbosa, D., \& Wagner, A. (2012). Learning in Ubiquitous Computing Environments. International Journal of Information and Communication Technology Education (IJICTE), 8(3), 64-77. doi http://dx.doi.org/10.4018/ jicte.2012070108

Billinghurst, M., \& Dunser, A. (2012). Augmented Reality in the classroom. Computer, 45(7) 56-63. doi http://dx.doi. org/10.1109/MC.2012.111

Castro, M., \& Lizasoain, L. (2012). Las técnicas de modelización estadística en la investigación educativa: minería de datos, modelos de ecuaciones estructurales y modelos jerárquicos lineales. Revista Española de Pedagogía, 251.

Caudill, J. (2007). The growth of m-learning and the growth of mobile computing: Parallel developments. The International Review of Research in Open and Distance Learning, 8(2).

CEDEFOP (2010). The development of national qualifications frameworks in Europe. Working Paper, 8. Luxembourg: Publications Office of the European Union.

Cope, B., \& Kalantzis, M. (2009). Ubiquitous Learning. Exploring the anywhere/anytime possibilities for learning in the age of digital media. United States: University of Illinois Press.

De Pablos, J., Colas, P., \& González, T. (2010). Factores facilitadores de la innovación con TIC en los centros escolares. Un análisis comparativo entre diferentes políticas educativas autonómicas. Revista de Educación, 352, 23-51.

D'Orio, W. (2011). iStudent. Scholastic Administrator, 10(5), 46-50.

Dublin Descriptors (2005). Shared "Dublin" descriptors for the Bachelor's, Master's and Doctoral awards. (Draft 1.31 working document on JQI meeting in Dublin. 2004PC).

European Commission (2010). The social dimension of education and training. European Union.

Feldman, R., \& Sanger, J. (2006). The Text Mining Handbook: Advanced Approaches in Analyzing Unstructured Data. United Kingdom: Cambridge University Press. doi http://dx.doi.org/10.1017/CBO9780511546914

Franklin, T. (2011). Mobile Learning: At the Tipping Point. Turkish Online Journal Of Educational Technology-TOJET, 10(4), 261-275.

García-Aracil, A., \& Van der Velden, R. (2008). Competencies for Young European Higher Education Graduates: Labor Market Mismatches and their Payoffs. Higher Education, 55, 219-239. doi http://dx.doi.org/10.1007/s10734-0069050-4

Goral, T. (2011). Take II Tablets. University Business, 46-49.

Harrold, R. (2012). Measuring the Effect of iPads in the Classroom. International Educator, 26(4), 5.

Hine, C. (2007). Multi-sited Ethnography as a Middle Range Methodology for Contemporary STS. Science, Technology, and Human Values, 32(6), 652-671. doi http://dx.doi.org/10.1177/0162243907303598

Mobile Life (2012). Mobile Life (report). Retrieved from http://discovermobilelife.com

La sociedad en red (report) (2011). Ministerio de Industria, Energía y Turismo. Retrieved from http://www.ontsi.red.es/ ontsi/sites/default/files/la_sociedad_en_red_2011_ed2012.pdf

Marcus, G. (1995). Ethnography In/Of the Word System: The Emergence of Multi-Sited Ethnography. Annual Review of Anthropology, 24, 95-117. doi http://dx.doi.org/10.1146/annurev.an.24.100195.000523

Miner, G., Elder, J., Hill, T., Nisbet, R., Delen, D., \& Fast, A. (2012). Practical Text Mining and Statistical Analysis for Nonstructured Text Data Applications. London: Oxford Academic Press. 
Murphy, G. (2011). Post-PC devices: A summary of early iPad technology adoption in tertiary environments. E-Journal of Business Education \& Scholarship of Teaching, 5(1), 18-32.

Murray, O., \& Olcese, N. (2011). Teaching and Learning with iPads, Ready or Not? Techtrends: Linking Research And Practice To Improve Learning, 55(6), 42-48.

Pachler, N., Bachmair, B., \& Cook, J. (2010). Mobile learning: structures, agency, practices. New York: Springer. doi http:// dx.doi.org/10.1007/978-1-4419-0585-7

Sevillano, M. L., \& Quicios, M. P. (2012). Indicadores del uso de competencias informáticas entre estudiantes universitarios. Implicaciones formativas y sociales. Revista Teoría de la Educación, 24.

Siemens, G., \& Baker, R. (2012). Learning Analytics and Educational Data Mining: Towards Communication and Collaboration. Second International Conference on Learning Analytics and Knowledge (LAK12). doi http://dx.doi. org/10.1145/2330601.2330661

Van't Hooft, M., \& Swan, K. (2007). Ubiquitous computing in education: Invisible technology, visible impact. London: Lawrence Erlbaum Associates.

Vázquez, E. (2012). Mobile Learning with Twitter to Improve Linguistic Competence at Secondary Schools. The New Educational Review, 29(3), 134-147.

Villa, A., \& Poblete, M. (dirs.) (2007) Aprendizaje basado en competencias. Una propuesta para la evaluación de las competencias genéricas. Bilbao: Mensajero/ICE Universidad de Deusto.

Walters, E., \& Baum, M. (2011). Will the iPad Revolutionize Education? Learning \& Leading With Technology, 38(7), 6-7. Witten, I., \& Frank, E. (2005). Data mining: Practical Machine Learning Tools and Techniques. San Francisco: Morgan Kaufmann Publishers.

\begin{abstract}
About the Authors

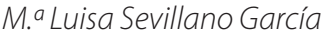

mlsevillano@edu.uned.es

Professor, National University of Distance Education (UNED), Spain

Professor of Teaching and School Organisation at the National University of Distance Education (UNED), Spain. She holds a doctorate in Education Sciences. She is the director of the journal Enseñanza\&Teaching and a scientific advisor for several national and international journals. Her research and publications are related to the sphere of mass media, new technologies, teaching and learning strategies, and curricular innovation. She has managed the Radio y Medios Audiovisuales centre at the UNED, as well as formative projects in several Latin American countries. She has organised and managed UNED summer courses and teaching staff training courses on media and strategies. She has supervised more than 35 doctoral theses and 70 research works, and has participated in nearly 100 national and international congresses.
\end{abstract}




\author{
Esteban Vázquez Cano \\ evazquez@edu.uned.es \\ Lecturer, National University of Distance Education (UNED), Spain
}

He holds a doctorate in Education Sciences with a special award (National University of Distance Education, UNED, Spain). He holds a bachelor's degree in English and Romance Philology (Complutense University of Madrid, UCM) and in Spanish Philology (UNED). He was a secondary school teacher in the United States and in several Spanish schools, an education inspector and a lecturer in the Faculty of Education at the University of Castilla-La Mancha (UCLM). He has done research internships at the Free University of Bozen-Bolzano, Italy, at the University of Illinois at Urbana-Champaign, United States, and at Stockholm University, Sweden. He has published various books and articles on educational supervision, school organisation and new technologies. He is a reviewer for JCR-indexed international journals and an active member of the American Educational Research Association. He is a lecturer in the Department of Teaching, School Organisation and Special Teaching at the UNED.

Universidad Nacional de Educación a Distancia

C/ Juan del Rosal, 14

Madrid (28040) Despacho 215

Spain

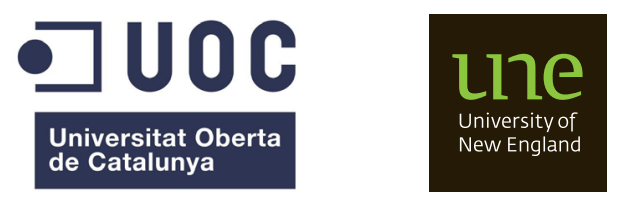

